\title{
HUBUNGAN LINGKUNGAN TERHADAP PENYALAHGUNAAN NARKOBA PADA REMAJA DI LEMBAGA PEMBINAAN KHUSUS ANAK KELAS II PEKANBARU
}

\author{
"Rika Sri Wahyuni, Febrianti, Yuni Maidar Sari \\ *Akademi Kebidanan Internasional Pekanbaru, email: rikasriwahyuni1303@gmail.com
}

\begin{tabular}{l} 
INFO ARTIKEL \\
\hline Riwayat Artikel: \\
Diterima: 16-05-2019 \\
Disetujui: 21-06-2019
\end{tabular}

\section{Kata Kunci:}

Hubungan

Lingkungan

Remaja

Penyalahgunaan

Narkoba

\begin{abstract}
ABSTRAK
Abstrak: Remaja memiliki rasa yang penuh dengan kegoncangan, mencari jati diri dan remaja ialah periode yang paling berat sehingga menimbulkan kenakalan remaja seperti penyalahgunaan narkoba. Salah satu penyalahgunaan narkoba adalah suasana lingkungan tidak sehat/ rawan terhadap narkoba yang merupakan tempat berinteraksinya seseorang baik itu lingkungan keluarga, masyarakat, teman sekolah/ sebaya. Tujuan penelitian ini adalah mengetahui adakah hubungan lingkungan terhadap penyalahgunaan narkoba pada remaja di Lembaga Pembinaan Khusus Anak Klas II Pekanbaru Tahun 2018. Metode penelitian ini menggunakan jenis penelitian kuantitatif dengan desain analitik dengan pendekatan cross sectional dan dilakukan pada bulan Januari-Maret 2018 di Lembaga Pembinaan Khusus Anak Klas II Pekanbaru. Populasi dalam penelitian ini adalah sebanyak 56 remaja dan sampel yang diambil sebanyak 49 remaja dari data primer (kuesioner). Analisis data yang digunakan adalah analisis univariat dan bivariat dengan uji chi-square. Hasil analisis univariat dari 49 remaja yang menggunakan narkoba sebanyak $44,9 \%$ yang berpengaruh dengan lingkungan keluarga $47,2 \%$, lingkungan masyarakat $51,7 \%$, lingkungan teman sekolah/ sebaya $54,1 \%$. Dari uji chi square didapat tidak ada hubungan lingkungan keluarga, masyarakat, teman sekolah/ sebaya terhadap penyalahgunaan narkoba.
\end{abstract}

\begin{abstract}
Abstrack: Teenagers have a sense of jolting, self-seeking and teenagers are the toughest periods that lead to juvenile delinquency such as drug abuse The purpose of this study is to know whether there is an environmental relationship to drug abuse in adolescents at Special Education Institution of Children Class II Pekanbaru Year 2018. This research method using the type of quantitative research with analytical design with cross sectional approach and conducted in February-March 2018 at the Institute of Special Development Children Class II Pekanbaru. The population in this study were as many as 56 teenagers and samples taken as many as 49 teenagers from the primary data (questionnaire). Data analysis used was univariate and bivariate analysis with chi-square test. From univariate analysis from 49 adolescents who use drugs as much as $44,9 \%$ which influenced with family environment 47,2\%, society environment $51,7 \%$, school friend / peer environment $54,1 \%$. From chi square test, there is no relation between family environment, society, school friend / peer to drug abuse. For that researchers expect that this research can be used as material comparison and reference to be added and equipped in the future.
\end{abstract}

\section{A. LATAR BELAKANG}

Remaja pada umumnya didefenisikan sebagai orang-orang yang mengalami masa peralihan dari masa kanak-kanak ke masa dewasa. Menurut (World Health Organization) WHO, remaja (adolescence) adalah mereka yang berusia 10-19 tahun. Sementara dalam terminologi lain menyebutkan anak muda (youth) untuk mereka yang berusia 15-24 tahun. Ini kemudian disatukan dalam sebuah terminologi kaum muda (young people) yang mencakup 10-24 tahun (Eny, 2011).

Masa remaja adalah masa yang penuh dengan kegoncangan, taraf mencari identitas diri dan merupakan periode yang paling berat sehingga menimbulkan kenakalan remaja Hurlock (1993). Banyak faktor yang menjadi penyebab kenakalan remaja yaitu : faktor yang ada dalam diri anak sendiri, faktor yang berasal dari lingkungan keluarga, faktor yang berasal dari lingkungan masyarakat, dan yang terakhir yaitu faktor yang bersumber dari sekolah (Marmi, 2013).

Banyak kerugian yang ditimbulkan dari kenakalan remaja seperti perkelahian, aborsi, miras, pemerkosaan, narkoba dan kenakalan-kenakalan yang lain. Kenakalan remaja seperti penggunaan narkoba dapat dipidana penjara sesuai dengan bunyi UndangUndang No. 35 Tahun 2009 Pasal 116 (1) (Siti, 2014).

Menurut World Drug Report Tahun 2012 yang diterbitkan oleh United Nations Office on Drugs and Crimes (UNODC), organisasi dunia yang mengenai masalah narkoba dan kriminal, diperkirakan terdapat 300 juta orang yang berusia produktif, antara 15-64 tahun yang mengkonsumsi narkoba, dan kurang lebih 
200 juta orang meninggal dunia setiap tahunnya, akibat penyalahgunaan narkoba (Fitri, 2016).

Berdasarkan pendataan dari aplikasi Sistem Informasi Narkoba (SIN) jumlah kasus narkotika yang berhasil diungkap selama 5 tahun terakhir dari tahun 2012-2016 per tahun sebesar 76,53\%. Kenaikan paling tinggi pada tahun 2013 ke 2014 yaitu 161,22\%. Tahun 2016 jumlah kasus narkotika yang berhasil diungkap adalah 868 kasus, jumlah ini meningkat 36,05\% dari tahun 2015 (BNN, 2017).

Data Badan Narkotika Nasional (BNN) terkait pengguna narkotika dan obat-obatan terlarang (narkoba) di 2014 menyebutkan, 22 persen pengguna narkoba di Indonesia merupakan pelajar dan mahasiswa (BNN, 2016). Sementara itu dilihat dari data Badan Narkotika Nasional Kota Pekanbaru (BNNP) (2017) ditemukan jumlah kejadian penyalahgunaan narkoba 151 kasus, 33\% diantaranya adalah remaja.

Penyalahgunaan narkoba adalah penggunaan narkoba bukan untuk tujuan pengobatan, dalam jumlah berlebih, secara kurang teratur dan berlangsung cukup lama sehingga menyebabkan gangguan kesehatan fisik, mental, dan kehidupan sosial si pengguna. Orang lain menggunakan narkoba karena berbagai alasan seperti mengatasi stres (situational use). Biasanya orang mulai mencoba narkoba (experimental use) karena ditawarkan teman. Namun, ketika penggunanya sudah begitu rupa sehingga menimbulkan dampak buruk terhadap jasmani, mental, dan kehidupan sosial atau pekerjaannya berarti ia sudah menyalahgunakan narkoba (abuse). Dan bila bertambah banyak makan akan menimbulkan ketergantungan (Lydia, 2006).

Salah satu faktor penyalahgunaan narkoba ialah lingkungan. Kondisi lingkungan masyarakat yang tidak sehat atau rawan, dapat menjadi faktor terganggunya perkembangan jiwa kearah perilaku yang menyimpang yang pada akhirnya terlibat penyalahgunan atau ketergantungan narkoba. Peranan lingkungan sangat menentukan bagi pertumbuhan dan perkembangan jiwa pribadi seseorang. Bila masyarakat di lingkungan itu solid berkepribadian santun ramah dan komunikatif, maka pda umumnya anak - anak itupun kelihatan baik - baik, pintar dan cerdas tidak mudah terpengaruh dengan perbuatan tercela begitu pun sebaliknya (Daru, 2016).

Hasil penelitian yang dilakukan oleh Dwi (2016) tentang Hubungan Lingkungan Keluarga Terhadap Penyalahgunaan Narkoba Pada Remaja dimana pengaruh antara keharmonisan keluarga terhadap penyalahgunaan NAPZA pada remaja menjadi penyebab remaja menggunakan NAPZA. Remaja yang memiliki keluarga tidak harmonis berisiko 6,179 kali lebih besar menjadi penyalahgunaan NAPZA dibandingkan remaja yang memiliki keluarga harmonis (Dwi, 2016).

Dari latar belakang diatas maka peneliti tertarik untuk melakukan penelitian dengan judul "Hubungan Lingkungan terhadap Penyalahgunaan Narkoba pada Remaja di Lembaga Pembinaan Khusus Anak Klas II Pekanbaru".

\section{B. METODE PENELITIAN}

Penelitian ini menggunakan rancangan crosssectional, penelitian ini melihat hubungan Lingkungan terhadap Penyalahgunaan narkoba pada remaja di lembaga pembinaan khusus anak klas II Pekanbaru pada bulan Januari - Maret 2018 Populasi dalam penelitian ini adalah semua Tahanan LPKA Klas II Pekanbaru, yaitu berjumlah 56 orang, dengan jumlah sampel 49 orang yang diambil secara quota sampling yaitu pengambilan sampel secara quota dilakukan dengan cara menetapkan sejumlah anggota sampel secara quotum atau jatah.

Pengumpulan data dilakukan dengan cara mengisi kuesioner berupa tabel ceklist dengan hasil ukur untuk semua variable, baik variable lingkungan keluarga, lingkungan masyarakat, lingkungan sebaya maupun penyalah gunaan narkoba adala ya dan tidak.

\section{HASIL DAN PEMBAHASAN}

\section{Analisis Univariat}

Dari hasil penelitian dan telah dilakukan analisis diperoleh data yang dijabarkan dalam table berikut:

TABEL 1

Distribusi Frekuensi Lingkungan Keluarga Pada Remaja di Lembaga Pembinaan Khusus Anak Klas II Pekanbaru

\begin{tabular}{llll}
\hline No & $\begin{array}{c}\text { Lingkungan } \\
\text { Keluarga }\end{array}$ & Frekuensi & $\begin{array}{l}\text { Persentase } \\
\text { (\%) }\end{array}$ \\
\hline 1. & Ya & 36 & $73,5 \%$ \\
2. & Tidak & 13 & $26,5 \%$ \\
\hline & Jumlah & 49 & $100 \%$ \\
\hline
\end{tabular}

Sumber : Analisis Data Primer, 2018

Dari tabel 1, dapat dilihat dari 49 remaja yang berada di Lembaga Pembinaan Khusus Anak Klas II Pekanbaru sebagian besar dipengaruhi oleh kondisi keluarga yaitu 73,5\% (36 remaja) sedangkan remaja yang tidak dipengaruhi oleh kondisi keluarga sebanyak $13 \%$ (13 remaja).

Keluarga sebagai unit sosial terkecil dalam masyarakat mempunyai peranan penting sebagai latar belakang penyalahgunaan zat adiktif. Peran orang tua dan kondisi keluarga mempengaruhi perkembangan kepribadian anak. Apakah kepribadian anak akan rentan atau tidak terhadap penyalahgunaan zat adiktif tergantung dari cara pendidikan orang tua (ayah dan ibu) dan suasana rumah tangga kondusif atau tidak. Orang tua dan keluarga dapat menyebabkan seseorang tergolong untuk menyalahgunakan narkotika, apabila kondisi orang tua atau keluarga tidak mampu menghayati perkembangan dan aspirasi anaknya, serta lemah dalam memberikan pengarahan dan pengawasan. Adanya situasi kehidupan orang tua yang broken home (Adam, 2012).

Hal ini sesuai dengan penelitian yang peneliti lakukan di Lembaga Pembinaan Khusus Anak Klas II Pekanbaru Tahun 2018 diperoleh sebanyak 73,5\% remaja berasal dari keluarga yang terkait penyalahgunaan narkoba/ broken home.

Data ini sesuai dengan hasil penelitian yang dilakukan Komariah (2010) bahwa faktor eksternal penyebab penyalahgunaan narkoba di lingkungan siswa (studi kasus SMP X Palembang) menunjukkan 
adalah kurang perhatian orang tua $52 \%$, broken home $45 \%$.

Dari data tersebut peneliti berasumsi bahwa keluarga merupakan pondasi pertama dalam membentuk kepribadian remaja dimana keluarga dapat menanamkan nilai agama dan interaksi yang baik pada anggota keluarganya, hal ini dapat menghindari dari pengaruh negative seperti kenakalan remaja maupun penyalahgunaan narkoba sesuai dengan teori yang dikemukakan oleh Sudarsono (2004) keluarga mempunyai peran yang sangat penting dalam memberikan pendidikan dan pembentuk karakter pada anak. Keluarga tidak akan bisa lepas dalam mengasuh seorang anak mulai dari pertumbuhan sampai perkembangan anak dalam keluarga.

TABEL 2

Distribusi Frekuensi Lingkungan Masyarakat Pada Remaja di Lembaga Pembinaan Khusus Anak Klas II Pekanbaru

\begin{tabular}{llll}
\hline No & $\begin{array}{l}\text { Lingkungan } \\
\text { Masyarakat }\end{array}$ & Frekuensi & $\begin{array}{l}\text { Persentase } \\
\text { (\%) }\end{array}$ \\
\hline 1. & Ya & 20 & $59,2 \%$ \\
2. & Tidak & 29 & $40,8 \%$ \\
\hline Jumlah & 49 & $100 \%$ \\
\hline
\end{tabular}

Sumber: Analisis Data Primer, 2018

Dari tabel 2, dapat dilihat dari 49 remaja yang berada di Lembaga Pembinaan Khusus Anak Klas II Pekanbaru sebagian besar dipengaruhi oleh lingkungan masyarakat sebanyak 59,2\% (29 orang) sedangkan yang tidak dipengaruhi oleh likungan masyarakat sebesar 40,8\% (20 orang).

Kondisi lingkungan sosial yang tidak sehat atau rawan merupakan faktor terganggunya jiwa atau kepribadian remaja kearah perilaku menyimpang yang pada gilirannya terlibat penyalahgunaan zat adiktif. Lingkungan yang rawan tersebut antara lain : tempat hiburan yang buka hingga larut malam bahkan hingga dini hari di mana sering digunakan sebagai tempat transaksi dan pelacuran, perumahan yang padat kumuh, banyaknya penertiban, tontonan, TV dan sejenisnya yang bersifat pornografi, kekerasan dan kriminalitas antar warga dan antar sekolah (Ratna, 2017).

Hal ini sesuai dengan penelitian yang peneliti lakukan di Lembaga Pembinaan Khusus Anak Klas II Pekanbaru Tahun 2018 diperoleh sebanyak 59,2\% memiliki pengaruh terhadap lingkungan masyarakat.

Data ini sesuai dengan penelitian yang dilakukan oleh Ratna (2017) hasil penelitian menujukkan bahwa frekuensi lingkungan yang mendukung menggunakan zat adiktif sebesar 25 responden $(55,6 \%)$ hal ini disebabkan lingkungan tempat tinggal siswa atau remaja rawan terhadap penyalahgunaan zat adiktif dan juga tidak adanya mata pelajaran di sekolah yang mengajarkan tentang bahaya zat adiktif dilingkungan sekolah ataupun tempat tinggal mereka.

Dari data tersebut peneliti berasumsi bahwa pentingnya ada penyuluhan dan informasi bahaya dan dampak narkoba pada masyarakat karena jika masyarakat mengetahui bahaya dan dampak narkoba maka akan dapat mengurangi penyalahgunaan narkoba.
TABEL 3

Distribusi Frekuensi Lingkungan Teman Sekolah/Sebaya Pada Remaja di Lembaga Pembinaan Khusus Anak Klas II Pekanbaru

\begin{tabular}{cccc}
\hline No & $\begin{array}{c}\text { Lingkungan } \\
\text { Teman } \\
\text { Sekolah/ } \\
\text { Sebaya }\end{array}$ & Frekuensi & $\begin{array}{c}\text { Persentase } \\
\text { (\%) }\end{array}$ \\
\hline 1. & Ya & 37 & $75,5 \%$ \\
2. & Tidak & 12 & $24,5 \%$ \\
\hline & Jumlah & 49 & $100 \%$ \\
\hline
\end{tabular}

Dari tabel 3, dapat dilihat dari 49 remaja yang berada di Lembaga Pembinaan Khusus Anak Klas II Pekanbaru sebagian besar dipengaruhi oleh lingkungan teman sekolah sebanyak 75,5\% (37 orang) sedangkan yang tidak dipengaruhi oleh lingkungan teman sekolah sebanyak 24,5\% (12 orang).

Seseorang yang menjadi pecandu narkotika pada dasarnya adalah orang-orang yang tidak mempunyai kepribadian yang mantap sehingga mudah dipengaruhi oleh orang lain terutama teman sebaya dan lingkungan. Adanya rasa ingin tahu dan ingin mencoba-oba, pengaruh dari teman agar dapat diterima dalam lingkungan mereka atau untuk menunjukkan rasa solidaritas, untuk melarikan diri dan untuk memperoleh rasa aman (Adam, 2012).

Pengaruh teman sebaya dapat menciptakan keterikatan dan kebersamaan, sehingga yang bersangkutan sukar melepaskan diri. Pengaruh teman sebaya tidak hanya pada saat mengenal zat adiktif,melainkan juga yang menyebabkan seseorang menjadi ketergantungan terhadap zat adiktif (Ratna, 2017).

Hal ini sesuai dengan penelitian yang peneliti lakukan di Lembaga Pembinaan Khusus Anak Klas II Pekanbaru Tahun 2018 diperoleh 75,5\% memiliki lingkungan teman sekolah/ sebaya. Hasil penelitian ini didukung juga dengan hasil penelitian Ratna (2017) hasil penelitian menunjukkan frekuensi teman sebaya yang berperan dalam menggunakan zat adiktif sebesar $63,9 \%$.

Dari data tersebut peneliti berasumsi bahwa teman sebaya mempunyai peranan yang cukup penting bagi perkembangan kepribadian seseorang. Pada masa remaja adalah masa ingin tahu juga penuh kegoncangan/ labil pada suatu keputusan seperti penyalahgunaan narkoba. Oleh karena itu seseorang harus pandai mencari teman pada masa pembentukan kepribadian.

TABEL 4

Distribusi Frekuensi Penyalahgunaan Narkoba Pada Remaja di Lembaga Pembinaan Khusus Anak Klas II Pekanbaru

\begin{tabular}{cccc}
\hline No & $\begin{array}{c}\text { Penyalahgunaan } \\
\text { Narkoba }\end{array}$ & Frekuensi & $\begin{array}{c}\text { Persentase } \\
\text { (\%) }\end{array}$ \\
\hline 1. & Ya & 22 & $44,9 \%$ \\
2. & Tidak & 27 & $55,1 \%$ \\
\hline \multicolumn{4}{c}{ Sumber: Analisis Data Primer, 2018} \\
\hline
\end{tabular}

Dari tabel 4, dapat dilihat dari 49 remaja yang berada di Lembaga Pembinaan Khusus Anak Klas II Pekanbaru sebagian remaja menggunakan Narkoba 
yaitu $44,9 \%$ (22 orang) dan yang tidak menggunakan narkoba yaitu $55,1 \%$ (27 orang).

Narkoba dibagi menjadi 3 jenis yaitu narkotika, psikotropika, dan zat adiktif lainnya. Narkotika adalah zat atau obat yang berasal dari tanaman atau bukan tanaman, baik sintesis maupun bukan sintesis yang didapat yang dapat menyebabkan penurunan atau perubahan kesadaran dan hilangnya rasa. Psikotropika adalat zat atau obat bukan narkotika yang memiliki khasiat psikoaktif menyebabkan perubahan khas pada aktivitas normal dan prilaku. Zat adiktif adalah zat-zat selain narkotika dan psikotropika yang dapat menimbulkan ketergantungan (Partodiharjo, 2008).

Ketergantungan obat adalah adanya kebutuhan secara psikologis terhadap suatu obat dalam jumlah yang makin lama bertambah besar untuk menghasilkan efek yang diharapkan (Prawiroharjo, 2012). Penyalahgunaan narkoba masih terjadu pada remaja karena remaja merupakan masa yang penuh kegocangan dan mudah untuk dipengaruhi.

Hasil penelitian yang peneliti lakukan mayoritas menggunakan narkoba sebanyak $44,9 \%$, data ini sesuai dengan penelitian yang dilakukan Ratna (2017) yang dilakukan di SMP Negeri o5 Kendari, bahwa dari 84 siswa kelas VIII yang dijadikan sebagai sampel penelitian ditemukan 36,9\% siswa yang menggunakan zat adiktif.

Dari data diatas peneliti berasumsi bahwa adanya penurunan terhadap penyalahgunaan narkoba pada remaja yang bias disebabkan oleh beberapa faktor yaitu adanya kesadaran remaja terhadap dampak dan bahaya narkoba dan juga didukung dengan menanamkan ilmu agama yang kuat pada remaja.

\section{Analisis Bivariat}

\section{TABEL 5}

Hubungan Lingkungan Keluarga Terhadap

Penyalahgunaan Narkoba Pada Remaja di Lembaga Pembinaan Khusus Anak

$$
\text { Klas II Pekanbaru }
$$

\begin{tabular}{|c|c|c|c|c|c|c|c|}
\hline \multirow{3}{*}{$\begin{array}{l}\text { Lingku } \\
\text { ngan } \\
\text { Keluar } \\
\text { ga }\end{array}$} & \multicolumn{4}{|c|}{$\begin{array}{c}\text { Penyalahgunaan } \\
\text { Narkoba }\end{array}$} & \multirow{2}{*}{\multicolumn{2}{|c|}{ Total }} & \multirow{2}{*}{$\begin{array}{l}P \\
\text { valu } \\
\boldsymbol{e}\end{array}$} \\
\hline & \multicolumn{2}{|c|}{ Ya } & \multicolumn{2}{|c|}{ Tidak } & & & \\
\hline & $\mathrm{N}$ & $\%$ & $\mathrm{~N}$ & $\%$ & $\mathrm{~N}$ & $\%$ & \\
\hline $\mathrm{Ya}$ & 17 & 47,2 & 19 & 52,8 & 36 & 100 & 0,827 \\
\hline Tidak & 5 & 38,4 & 8 & 61,6 & 13 & 100 & \\
\hline Jumlah & 22 & 44,8 & 27 & 55,2 & 49 & 100 & \\
\hline
\end{tabular}

Sumber : Analisis Data Primer, 2018

Berdasarkan tabel 5, hasil analisis hubungan antara lingkungan keluarga terhadap penyalahgunaan narkoba diperoleh bahwa dari 36 remaja yang dipengaruhi oleh lingkungan keluarga $47,2 \%$ terkait penyalahgunaan narkoba dan $52,8 \%$ tidak terkait penyalahgunaan narkoba dan dari 13 remaja yang tidak dipengaruhi oleh lingkungan keluarga 38,4\% terkait penyalahgunaan narkoba dan $61,6 \%$ tidak terkait penyalahgunaan narkoba.

Kesibukan orang tua yang terlalu padat akan membuat berkurangnya waktu bersama anaknya sehingga akan lupa dengan hak seorang anak untuk mendapatkan kasih sayang dari orang tua. Hal ini akan mempengaruhi baik fisik, mental, maupun sosial emosionalnya, sehingga anak akan cenderung lari dalam pergaulan negatif di luar rumah. Sugiyatno (2010), menyebutkan bahwa frekuensi pertemuan orang tua dengan anak semakin tinggi maka akan semakin besar pengaruh positif kepada anak, karena dengan semakin tinggi frekuensi pertemuan orang tua dengan anak, akan membuat komunikasi orang tua dengan anak akan lebih efektif, sehingga anak akan merasa mendapat perhatian dari orang tua.

Hasil uji chi-square Hubungan Lingkungan Keluarga Terhadap Penyalahgunaan Narkoba Pada Remaja Di Lembaga Pembinaan Khusus Anak Klas II Pekanbaru Tahun 2018 adalah Ha ditolak, dimana $p$ value $>0,05$ yaitu $0,827>0,05$ sehingga tidak ada Hubungan Lingkungan Keluarga Terhadap Penyalahgunaan Narkoba Pada Remaja Di Lembaga Pembinaan Khusus Anak Klas II Pekanbaru Tahun 2018.

Penelitian ini sesuai dengan penelitian yang dilakukan Dwi Oktavia (2016) bahwa tingkat signifikansi pola asuh orang tua 0,302 yang artinya tidak ada pengaruh penyebab pola asuh orang tua terhadap penyalahgunaan NAPZA pada remaja di BNN Kota Surabaya.

Dari hasil penelitian peneliti berasumsi bahwa keluarga yang harmonis dan keluarga yang selalu menanamkan nilai-nilai moral dan nilai agama pada anaknya akan dapat melindungi dan mencegah terjadinya hal menyimpang seperti penyalahgunaan narkoba meskipun dalam keluarga ada yang terkait penyalahgunaan narkoba dan keluarga mengalami broken home. Namun, jika seseorang anak telah memiliki karakter yang kuat maka ia akan mampu mengatasi gangguan untuk ajakan yang salah.

TABEL 6

Hubungan Lingkungan Masyarakat Terhadap Penyalahgunaan Narkoba Pada Remaja di Lembaga Pembinaan Khusus Anak Klas II Pekanbaru

\begin{tabular}{|c|c|c|c|c|c|c|c|}
\hline \multirow{3}{*}{$\begin{array}{l}\text { Lingku } \\
\text { ngan } \\
\text { Masya } \\
\text { rakat }\end{array}$} & \multicolumn{4}{|c|}{$\begin{array}{c}\text { Penyalahgunaan } \\
\text { Narkoba }\end{array}$} & \multirow{2}{*}{\multicolumn{2}{|c|}{ Total }} & \multirow{2}{*}{$\begin{array}{l}P \\
\text { valu } \\
\text { e }\end{array}$} \\
\hline & Ya & & & & & & \\
\hline & $\mathrm{N}$ & $\%$ & $\mathrm{~N}$ & $\%$ & $\mathrm{~N}$ & $\%$ & \\
\hline $\mathrm{Ya}$ & 15 & 51,7 & 14 & 48,3 & 29 & 100 & 28 \\
\hline
\end{tabular}

\begin{tabular}{lllllll} 
Tidak & 7 & 35 & 13 & 65 & 20 & 100 \\
\hline Jumlah & 22 & 44,8 & 27 & 55,2 & 49 & 100 \\
\hline
\end{tabular}

Sumber : Analisis Data Primer, 2018

Dari table 6 hasil analisis hubungan antara lingkungan keluarga terhadap penyalahgunaan narkoba diperoleh bahwa dari 29 remaja yang dipengaruhi lingkungan masyarakat $51,7 \%$ terlibat penyalahgunaan narkoba dan $48,3 \%$ tidak. Dan dari 20 remaja yang tidak dipengaruh lingkungan masyarakat $35 \%$ terkait penyalahgunaan narkoba dan $65 \%$ tidak terkait penyalahgunaan narkoba.

Kondisi lingkungan sosial yang tidak sehat atau rawan merupakan faktor terganggunya jiwa atau kepribadian remaja kearah perilaku menyimpang yang pada gilirannya terlibat penyalahgunaan zat adiktif. Lingkungan yang rawan tersebut antara lain : tempat hiburan yang buka hingga larut malam bahkan hingga dini hari di mana sering digunakan sebagai tempat transaksi dan pelacuran, perumahan yang padat 
kumuh, banyaknya penertiban, tontonan, TV dan sejenisnya yang bersifat pornografi, kekerasan dan kriminalitas antar warga dan antar sekolah.

Hasil uji chi-square Hubungan Lingkungan Masyarakat Terhadap Penyalahgunaan Narkoba Pada Remaja Di Lembaga Pembinaan Khusus Anak Klas II Pekanbaru Tahun 2018 adalah Ha ditolak, dimana $p$ value $>0,05$ yaitu $0,387>0,05$ sehingga tidak ada Hubungan Lingkungan Masyarakat Terhadap Penyalahgunaan Narkoba Pada Remaja Di Lembaga Pembinaan Khusus Anak Klas II Pekanbaru Tahun 2018.

Hasil penelitian ini tidak sejalan dengan penelitian yang dilakukan oleh Jaji (2012) di Instalasi Narkoba RS Jiwa Prof. Dr. HB Sa'anin Padang, hasil penelitian tersebut menyatakan bahwa ada hubungan bermakna antara keberadaan narkoba/ keadaan lingkungan itu sendiri sebanyak 53,1 \% mendukung tindak penyalahgunaan narkoba.

Dari hasil penelitian peneliti berasumsi bahwa lingkungan masyarakat sangat berperan dalam kemungkinan terjerumusnya remaja terhadap penyalahgunaan narkoba. Oleh karena itu, masyarakat perlu mendorong peningkatan pengetahuan setiap anggota masyarakat tentang bahaya penyalahgunaan zat adiktif, perlu memberikan informasi kepada pihak yang berwajib jika ada pemakai atau pengedar zat adiktif di lingkungan tempat tinggal. Serta peran sekolah perlu memberikan wawasan yang cukup kepada remaja tentang bahaya penyalahgunaan narkoba. Lingkungan yang kaya akan ilmu pengetahuan akan menimbulkan kondisi lingkungan yang baik untuk tempat interaksinya seseorang.

TABEL 7

Hubungan Lingkungan Keluarga Terhadap

Penyalahgunaan Narkoba Pada Remaja di Lembaga Pembinaan Khusus Anak Klas II Pekanbaru

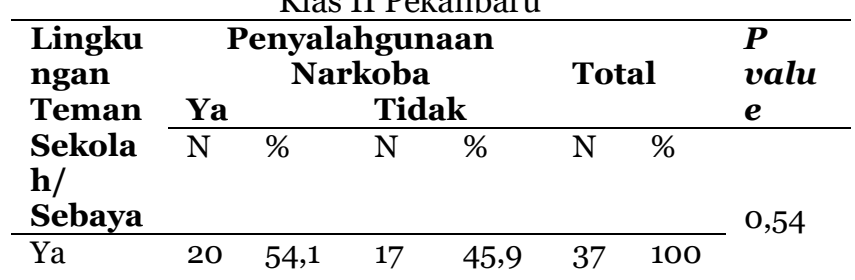

\begin{tabular}{ccccccc} 
Tidak & 2 & 16,7 & 10 & 83,3 & 12 & 100 \\
\hline Jumlah & 22 & 44,8 & 27 & 55,2 & 49 & 100 \\
Sumber : Analisis Data Primer, 2018 &
\end{tabular}

Dari hasil analisis hubungan antara lingkungan keluarga terhadap penyalahgunaan narkoba diperoleh bahwa dari 37 remaja yang dipengaruhi oleh lingkungan teman sekolah/ sebaya 54,1\% terkait penyalahgunaan narkoba dan 45,9\% tidak terkait penyalahgunaan narkoba. Dan dari 12 remaja yang tidak dipengaruhi oleh lingkungan teman sekolah/ sebaya $16,7 \%$ terkait penyalahgunaan narkoba dan $83,3 \%$ tidak terkait penyalahgunaan narkoba.

Tidak selamanya pergaulan dengan teman sebaya berpengaruh negatif, teman sebaya juga dapat memberikan pengaruh positif terhadap kehidupan remaja. Menurut Santrock (2007) teman sebaya merupakan sumber penting dukungan sosial yang berpengaruh terhadap rasa percaya diri remaja.
Dukungan emosional dan persetujuan sosial dalam bentuk konfirmasi dari orang lain merupakan pengaruh yang penting bagi rasa percaya diri remaja. Hubungan pribadi yang berkualitas memberikan stabilitas, kepercayaan, dan perhatian, dapat meningkatkan rasa kepemilikan, harga diri dan penerimaan diri. Dukungan interpersonal yang positif dari teman sebaya dapat meminimalisir faktor-faktor penyebab kegagalan prestasi.

Hasil uji chi-square Hubungan Lingkungan Teman Sekolah/ Sebaya Terhadap Penyalahgunaan Narkoba Pada Remaja Di Lembaga Pembinaan Khusus Anak Klas II Pekanbaru Tahun 2018 adalah Ha ditolak, dimana $p$ value $>0,05$ yaitu 0,054 > 0,05 sehingga tidak ada Hubungan Lingkungan Teman Sekolah/ Sebaya Terhadap Penyalahgunaan Narkoba Pada Remaja Di Lembaga Pembinaan Khusus Anak Klas II Pekanbaru Tahun 2018.

Hasil penelitian ini sejalan dengan penelitian yang dilakukan oleh Muhsinin (2017) menunjukan bahwa hubungan teman sebaya dengan kecenderungan menggunakan Narkotika, Psikotropika dan Zat Adiktif pada remaja di Banjarmasin dengan presentasi terbanyak adalah pada kategori teman sebaya postif dan kecenderungan menggunakan NAPZA rendah yaitu sebanyak 103 responden (41,2\%).

Dari hasil penelitian diatas peneliti berasumsi bahwa tidak semua teman dapat membawa ke arah yang tidak baik seperti mengajak menggunakan narkoba karena bila seorang remaja sudah ditanamkan nilai moral dan agama dari keluarga maka akan membentuk sebuah kepribadian yang dapat membedakan hal yang baik dan yang buruk. Jadi,seorang remaja harus pandai dalam memilih teman yang dapat mengajak dan membawanya ke dalam hal yang positif bukan sebaliknya.

\section{SIMPULAN DAN SARAN}

Dari penelitian ini dapat disimpulkan bahwa tidak ada hubungan lingkungan keluarga, lingkungan masyarakat maupun lingkungan teman sebaya terhadap penyalahgunaan narkoba pada remaja di lembaga pembinaan khusus anak klas II Pekanbaru.

\section{UCAPAN TERIMA KASIH}

Penulis mengucapkan terimakasih kepala Kepala Lembaga Lembaga Pembinaan Khusus Anak Klas II Pekanbaru membantu peneliti dalam menyelesaikan penelitian

\section{DAFTAR RUJUKAN}

[1] BNN. (2016). Laporan Akuntabilitas BNN. Jakarta Timur: BNN.

[2] BNN. (2017). Sistem Informasi Narkoba. Jakarta Timur: BNN.

[3] BNNP. (2017). Data Kasus Narkoba. Pekanbaru. Pekanbaru: BNNP

[4] Hurlock, B..(2012). Psikologi Perkembangan. Jakarta: Erlangga.

[5] Jaji. (2009). Hubungan Faktor Sosial Dan Spiritual Dengan Risiko Penyalahgunaan NAPZA Pada Remaja SMP Dan SMA di Kota Palembang 
[6] Marmi. (2013). Kesehatan Reproduksi. Yogyakarta: Pustaka Pelajar.

[7] Muhsinin. (2017). Pengaruh Teman Sebaya Terhadap Kecenderungan Menggunakan Napza Pada Remaja Di Banjarmasin. Banjarmasin. Banjarmasin

[8] Partodiharjo, S. (n.d.). Kenali Narkoba Dan Musuhi
Penyalahgunaannya. Jakarta: Erlangga.

[9] Ratna. (2017). Penyalahgunaan Zat Adiktif Pada Siswa Kelas VIII Di Sekolah Menengah Pertama Negeri 55 Kota Kendari.

[10] Sudarsono. (2004). Kenakalan Remaja. Jakarta: Rineka Cipta. 